\title{
II. Monográfico
}

\section{HISTORIA RECIENTE DE CHILE. PENSAR DESDE DENTRO, PENSAR DESDE AFUERA}

\section{Coordinado por}

Joan del Alcàzar Garrido Universitat de València 


\title{
Politics in History: The Chilean radical right in the 20 th century ${ }^{1}$
}

\author{
La Política en la Historia: la derecha \\ radical chilena en el siglo XX
}

\author{
Mario Sznajder ${ }^{2}$ \\ The Hebrew University of Jerusalem (Israel)
}

Recibido: 04-05-15

Aprobado: 02-06-15

\begin{abstract}
This work characterizes an important aspect of the political culture of the Chilean radical right in the 20th century: its use of history as a political tool and the introduction of political themes into the presentation of historical subjects or events. The main example is the reliance on the work of Diego Portales and his foundational role in the formation of the Chilean state and its institutions. The analysis describes the development of a Chilean radical right which ideologically relies on the work of serious historians but also "uses" history for contemporary political purposes. The
\end{abstract}

\footnotetext{
${ }^{1}$ This article has been developed from a research that began years ago and was presented in University of Vienna at a seminar of the Department of Latin American Studies, in January 2009 and in LASA-Chicago 2013.

2 (mario.sznajder@mail.huji.ac.il). Recent publications: Barahona de Brito, A., M. Sznajder, "The Politics of the Past: The Southern Cone and Southern Europe in Comparative Perspective" in Southern European Society and Politics 15 (3) 2010, published also in A. Costa Pinto and L. Morlino (Eds.) Dealing with the Legacy of Authoritarianism (London and New York: Routledge, 2011). Also as "A politica do pasado: America Latina e Europa do Sul" in A. Costa Pinto (ed.) A Sombra das Ditaduras (Lisboa: ICS, $2013)$ pp. (in Portuguese). Also in A. Costa Pinto, F. C. Palomares Martinho (eds.) O pasado que nao passao. A sombra das ditaduras na Europa do Sul e na America Latina (Rio de Janeiro: Civilizaçao Brasileira, 2013); M. Sznajder, "Israele e la Primavera araba," Il Mulino 4, 2011, also published as, M. Sznajder, "Israel y la Primavera Árabe," in Manuel Férez, Elisenda Balleste (Eds.); Medio Oriente y Norte de África. ¿Reforma, Revolución o Continuidad? (México: Senado de la República, 2011); L. Roniger, M. Sznajder, "Human rights and human rights violation in the Southern Cone," in Thomas Cushman (Ed.) Handbook of Human Rights (London and New York: Routledge, 2012); M. Sznajder, L. Roniger, C. A. Forment (eds.) Shifting Frontiers of Citizenship: The Latin American Experience (Leiden, Boston, MA: Brill, 2013); M. Sznajder (ed.) "Israel 2013” en Araucaria 30 (15), segundo semestre 2013; M. Sznajder, L. Roniger, The politics of exile in Latin America (New York, Cambridge: Cambridge University Press, 2009) and its Spanish translation, La política del destierro y el exilio en América Latina (México: Fondo de Cultura Económica, 2013).
} 
period analyzed is the 20th century in which Chile alternated between democracy and authoritarian dictatorships which were in a certain way influenced also by the radical right.

Key-words: Radical right, Conservative right, History, Politics, Corporativism, Subsidiarity, Chile

\section{Resumen}

Este trabajo caracteriza un aspecto importante de la cultura política de la extrema derecha chilena en el siglo XX: su uso de la historia como instrumento político y la introducción de asuntos políticos contemporáneos en su presentación de sujetos o eventos históricos. El ejemplo principal de ese aspecto es el apoyo de la extrema derecha en el trabajo de Diego Portales y su papel fundacional en la formación del estado chileno y sus instituciones. El análisis describe el desarrollo de la extrema derecha chilena que se apoya, en sus análisis, en el trabajo de serios historiadores pero "usa" la historia para propósitos políticos contemporáneos. El período analizado es el siglo XX en el que Chile alternó entre democracia y dictaduras autoritarias que fueron, en cierta medida, influenciadas por la extrema derecha.

Palabras-clave: Extrema Derecha, Derecha Conservadora, Historia, Política, Corporativismo, Subsidiariedad, Chile.

\section{Introduction}

One of the most used -and abused- forms of acquisition of political legitimacy involves mixing political and historical arguments, rewriting -or rather re-interpreting- past history according to contemporary political circumstances and needs, as well as using historical examples -real or mythical, contextualized or taken out of context- in order to claim legitimacy and right in both senses. Being right, historically, and therefore, having the right to rule, or at least the right to impose their ideological position.

The concept of the right is, in politics, an elusive one, since it includes antireform and anti-revolutionary movements generally defined as conservative and also radical right groups generally associated with xenophobic and sometimes racist attitudes but committed to radical change ${ }^{3}$. In general, the political radical right tends to reject rationalism and reason as bases for political action, denying the possible utility of political constructivism. Instead, the most

${ }^{3}$ Desmond King, 'Right,' in Joel Krieger (ed.), The Oxford Companion to Politics of the World (New York, Oxford: Oxford University Press, 1993) 790-791. 
conservative right believes tradition and custom to be a much sounder basis foundation for politics. The radical right and its extreme version, fascism, tends to adopt versions of political constructivism based on the non-rational parts of the human nature and especially the irrational behaviour of whom they see as the main modern political actor, that is, the crowd or mass ${ }^{4}$. Therefore, this kind of politicians abandon rational, consensual decision making and government through representation based on universal criteria of citizenship — criteria that serve as basis for modern democracy - in favour of various forms of qualified representation and authoritarianism.

Political nationalism is one of the main features of an era in which polities are organized as nation-states. Whether we adopt Gellner's functionalist approach that attributes nationalism to the dislocations caused by modernity and industrialization as well as by the development of the institutions of the modern state; or Anthony Smith's views, turning to primordial identities elaborated through culture and politics; or Benedict O. Anderson's use of literacy and the construction of imagined communities, it is difficult to avoid seeing the centrality of the concept nation, and its corollary, political nationalism, as a main component of the Latin American right ${ }^{5}$.

In this work, we will try to analyse the relationship between contemporary politics and history through the lenses of nationalism, as an active and central part of the right in Chile and other Latin American countries. ${ }^{6}$ The claim of this work is that the use - and abuse- of history through the creation of myths and partial, biased and out of context readings of the past has played a central role in the evolution of the right in Latin America and particularly in Chile.

Chile's Parliamentarian Republic (1891-1925) was characterized by political patronage system and electoral corruption. The generalized feeling of moral decadence and crisis found important Chilean intellectual figures not only longing for the lost Portales order but harshly criticising - in nationalist terms - Chile's realities after a century of independence. Alberto Edwards, Francisco Encina, Tancredo Pinochet and Guillermo Subercaseaux expressed their criticism in different ways and there was an attempt to articulate a Nationalist Union -Unión Nacionalista- without much success. Griffin, dealing with Francisco Encina's historical revisionism writes:

It outrages scholars because of the cavalier way in which it disregards all the rules of the professional historian's craft; it outrages present day-liberals

\footnotetext{
4 The first theoretical background in this direction can be found in Gustave Le Bon, The crowd: $a$ study of the popular mind (London: T. Fisher Unwin, 1908).

5 See, Ernst Gellner, Nations and nationalism (Oxford: Basil Blackwell, 1983); Anthony Smith, The ethnic origins of nations (Oxford: Basil Blackwell, 1987); Benedict O. Anderson, Imagined communities: reflections on the origin and spread of nationalism (London: Verso, 1987).

${ }^{6}$ Ana Maria Alonso, 'The Effects of Truth: Re-Presentations of the Past and the Imagining of Community,' Journal of Historical Sociology, 1 (1) 1988, 33-57. This article provides a sound theoretical ground to the claims made in this work.
} 
because its attacks on Barros Arana and the whole liberal tradition in Chilean historiography; it shocks the filio-pietist sentiments of many by ruthlessly cutting down to size figures in a whole gallery of patri patriae and magnifying the historical role of other heroes; it titillates the Hispanist sentiment of one sector of the Chilean intellectual way while it infuriates the indigenistas and Americanists ${ }^{7}$.

Encina's nationalist political interpretations of Chilean realities, well presented in one of his most famous works: Nuestra inferioridad económica: sus causas, sus consecuencias published in 1911 before the foundation of the Nationalist Party in Chile in 1915, serve as an example of a trend that will grow, both in Chile and the rest of Latin America, along the $20^{\text {th }}$ century and the political crises involving nationalist groups ${ }^{8}$. Alberto Edwards Vives, a co-founder, with Encina, Subercaseaux, Galdames and Pinochet, of Chilean modern nationalism, inspired by Oswald Spengler's The Decline of the West, wrote many essays, articles and his main work, La fronda aristocrática en Chile in which a claim for modern nationalist authoritarianism is called to replace the egoistic and decadent rule of Chile's parliamentarian oligarchy'.

A precedent to this brand of nationalist historical revisionism can be found in the work of Nicolás Palacios, who tried to explain Chile's military superiority over its neighbours during the $19^{\text {th }}$ century as a result of the miscegenation between two warrior races: the Germanic Goths (Godos) from Northern Spain, settling in Chile on behalf of the Spanish Crown, and the Araucanian (Mapuche) Indians, defending their soil ${ }^{10}$.

\section{Latin American radical right}

In Argentina, the historian Ricardo Rojas used similar arguments to those employed by Encina, but in a different context. Being Argentina at the beginning of the $20^{\text {th }}$ century a land of immigration, Rojas was preoccupied with the impact of this phenomenon in his own nation. Rojas wrote against the British imperialism as we all as against the uncontrolled Italian and Jewish

\footnotetext{
${ }^{7}$ Charles C. Griffin, 'Francisco Encina and Revisionism in Chilean History,' Hispanic American Historical Review, 37 (1) 1957, 2

${ }^{8}$ Francisco A. Encina, Nuestra inferioridad económica: sus causas, sus consecuencias (Santiago: Imprenta Universitaria, 1911). A serious personal and intellectual attack on Encina and his historical work is waged in Ricardo Donoso, Francisco A. Encina: Simulador (Santiago: Editorial Ricardo Neupert, 1969) 2 vols. See also, Guillermo Subercaseaux, Los ideales nacionalistas frente al doctrinarismo de nuestros partidos políticos históricos (Santiago: Imprenta Universitaria, 1918).

9 Alberto Edwards Vives, La fronda aristocrática en Chile (Santiago: Imprenta Nacional, 1928). Tancredo Pinochet, novelist, journalist and essay's writer was seen also as one of the main intellectual figures of Chilean nationalism in the first half of the $20^{\text {th }}$ century.

${ }^{10}$ Nicolás Palacios, La raza chilena: su nacimiento, nobleza de sus orígenes (Valparaíso: Imprenta y Litografía Alemana, 1904)
}

Araucaria. Revista Iberoamericana de Filosofía, Política y Humanidades, año 17, $\mathrm{n}^{\circ} 34$. Segundo semestre de 2015. Pp. 177-201. ISSN 1575-6823 e-ISSN 2340-2199 doi: 10.12795/araucaria.2015.i34.09 
immigration as dangers that, if combined with destructive individualism, liberalism's centrifugal tendencies and cosmopolitanism, could seriously damage the future of the Argentinean nation ${ }^{11}$.

The ideas circulated among nationalist intellectuals, willing readers and listeners who found political echo in the armed forces groups and especially in one of their main leaders in Chile, Colonel Carlos Ibáñez del Campo, who played a central role in the events of 1924-1925 which led to the enactment of a new constitution and the establishment of his own military rule between 1927 and $1931^{12}$.

Although every nationalism stressed local particularities, common features are present in all of them. In general, these interpretations are strongly anti-liberal and they do not lack a popular undertone, although this is tainted by anti-Marxism and an aversion to the idea of interclass war. The underpinnings of this kind of reading of past history are in the acceptance of the principle of private property and market economy, but strongly organized under the aegis of the state and in a productionist and authoritarian economicpolitical model. These ideas were linked to the origins of European fascism, but in their historical reading, were presented both as a reaction against what in the $20^{\text {th }}$ century terms could be classified as a moderate right, in its liberal or conservative forms. The use of historical myths, less of Golden Ages that were difficult to find in the convulsions of post-independence and nation-state building periods, and more of national heroes 'founding' the new nation, were a common feature of the countries in Latin America. San Martin and Rosas played that role in Argentina, Artigas, and Lavalleja in Uruguay, Rodríguez de Francia and the López (father and son) in Paraguay, O'Higgins and Portales in Chile, Bolivar in Venezuela and Colombia and also Santander in the later, and the emperors in Brazil, to mention just a few. David Brading considered all these figures were depicted by nationalist revisionist intellectuals more in terms of nationalism - founding fathers of the "nation"- than in terms of local patriotism $^{13}$. In general, an attack against the liberal oligarchic groups that were associated with stabilization and economic expansion was essential. Such were the cases against Argentina's liberals that defeated Juan Manuel de Rosas seen by Argentina historical revisionists as a founding figure of the country after San Martín. In Chile, Portales and Balmaceda were counterpoised to the

${ }^{11}$ For an excellent analysis of this point see David Rock, Authoritarian Argentina. The Nationalist Movement. Its History and its Impact (Berkeley, CA: California University Press, 1993) 44-45. See also, Ricardo Rojas, La restauración nacionalista, informe sobre la educación (Buenos Aires: Ministerio de Justicia e Instrucción Pública, 1909).

12 Jaime Etchepare J., Víctor García U., Mario Valdés U., 'La ideología nacionalista y su proyección partidista en Chile 1925-1973,' Politica y Geoestrategia 44 (1987) 20-21.

13 See, David Brading, 'Patriotism and the Nation in Colonial Spanish America,' in Luis Roniger, Mario Sznajder (eds.) Constructing Collective identities and Shaping Public Spheres. Latin American Paths (Brighton: Sussex Academic Press, 1998) 29-30. 
oligarchic parliamentarian republic. In Brazil, to a lesser extent, nationalists and the Açao Integralista Brasileira (Brazilian Integralist Action) saw in colonial times, in which Portuguese control and influence were feeble, the basis of the development of a Brazilian nation that crystallized politically in the imperial period and severely decayed during the Oligarchic Republic finally destroyed by the 1930 revolution. The Açao Integralista Brasilera stressed also another historical myth, in the Sorelian sense of the concept, built around the glorification of the Indians who inhabited the land of Brazil before the arrival of the Portuguese ${ }^{14}$. This came as a reaction against the Brazilian nationalist theories about 'whitening through immigration' which floated at the beginning of the $20^{\text {th }}$ century ${ }^{15}$.

It is true that nationalism in Argentina used the combination of the image of Rosas and anti-imperialism - especially against British imperialism, to generate mass appeal, while Chilean nationalism was of a more elitist character and Brazilian Integralist Action, although widely mobilizing, lasted for a relatively short period in the 1930's and was dissolved and persecuted by Vargas. ${ }^{16}$ Brazilian intellectuals as Oliveira Vianna and Torres influenced Integralism in their country. Oliveira Vianna expressed his ideas about the whitening of Brazil - embranquecimento- through declining fertility of the Afro-Brazilians and increasing European immigration ${ }^{17}$. Alberto Torres was even more influential, especially in the leader of Integralist Action, Plinio Salgado, through the theories of positive racial miscegenation ${ }^{18}$. While Gustavo Barroso, other main leader of Brazilian Integralism, preconized openly anti-Semitism, Plinio Salgado, the main leader, adopted a softer attitude in this area, nuanced by the above contradictions and paradoxes related to the national 'viability' of a society and a country in which ethnic miscegenation and even religious syncretism were a central part of life $^{19}$. All this could be seen in a historical conception of the foundational myth of Brazil presented by Plinio Salgado, the main leader of the AIB. The historical myth was built around the Paulista expeditions, or Bandeiras, who characterized colonial Brazil. Salgado, who

${ }^{14}$ Helgio Trindade, 'Fascism and Authoritarianism in Brazil under Vargas (1930-1945)1,' in Stein Ugelvik Larsen (ed.) Fascism Outside Europe (Boulder, CO: and New York: Social Science Monographs and Columbia University Press, 2001) 514.

15 Thomas E. Skidmore, Black into White. Race and Nationality in Brazilian Thought (Durham, NC: Duke University Press, 1993) 65-69.

${ }^{16}$ On a comparison between historical revisionism in the nationalist Right of Argentina, Brazil and Chile and the Radical Right in the three countries see, Sandra McGee Deutsch, Las derechas. The Extreme Right in Argentina, Brazil and Chile, 1890-1939 Stanford, CA: Stanford University Press, 1999) 327-328 et al.

${ }^{17}$ Francisco José de Oliveira Vianna, As Populaçoes Meridionais do Brasil; historia, organização, psycologia (Sao Paulo: Companhia Editora Nacional, 1933) 3rd Edition.

18 See Alberto Torres, O problema nacional brasileiro; introducção a um programma de organização nacional (Sao Paulo: Companhia editora nacional, 1933)

${ }^{19}$ For a more detailed analysis of the racial issue in Brazil see David Cleary, 'Race, nationalism and social theory in Brazil: rethinking Gilberto Freyre,' WPTC -99-09. 
in spite of European fascist influences, placed Catholic idealism in the centre of his views, saw in Brazilian colonial history a continuous tension between spiritual and material factors, coming together in his Integralist ideology ${ }^{20}$.

Intellectual nationalism has one of its most important examples in Argentinean nationalism until the assumption of power by Peron. The figure of Leopoldo Lugones, one of the most famous writers in the country and groups of less notorious intellectual figures and publicists such as Manuel Gálvez, the brothers Rodolfo and Julio Irazusta, and Arturo Jauretche, to mention just the most prominent examples, constitute various groups of the Argentinean radical righ $^{21}$. Here again, historians such as Rojas and Gálvez promote the importance of the Hispanic legacy and the anti-liberal ethos, as basis for Argentine's modern nationalism.

\section{Chile's rights}

Chile's reality suffers and reflects, to a great extent, developments abroad. Thus, ideas and political programs circulated and put into practice in Spain under the dictatorship of General Miguel Primo de Rivera -who found partial inspiration in Mussolini's fascism- were extrapolated and adapted into the Chilean reality.

The world economic crisis and its impact on Chile provided further arguments to extreme nationalists that appeared in the political scenario in 1932 under the banners of the Movimiento Nacional Socialista de Chile MNS. Historically, the intellectual leaders of the MNS relied on Palacios, Edwards, and Encina, but they also wrote pamphlets and books in which historical myths, such as the enhancing of Portales, played a central role in the construction of their nationalism ${ }^{22}$. Moreover, the transformation and adaptation of European fascist ideology to local needs produced an electoral party represented in Parliament that at the same time sent its militiamen to confront the left in the streets and publicly attacked liberal democracy in its publications and speeches. The double soul of Chile's Nacismo -Creole Nazism, written in Spanish with a c, playing parliamentary politics and

${ }^{20}$ Plinio Salgado, O que é o integralismo (Rio de Janeiro: Schmidt, 1935) 3. ed.

21 See Alberto Spektorowski, The Origins of Argentina's Revolution of the Right (Notre Dame, IND: Notre Dame University Press, 2003). Spektorowski attacks the thesis held by authors such as Buchrucker, Hernández Arregui and Ramos claiming that Argentina's nationalism was nostalgic and anti-modernist. Spektorowski stresses the fascist influences - including the use of mobilizing myths and the interplay between history and politics - on Argentina's Radical Right.

22 See, Jorge González von Marees, El problema del hambre. Su causas y solución (Santiago: Ercilla, 1937) and Idem, El mal de Chile. Sus causas y remedios (Santiago: Talleres Gráficos Portales, 1940) and Carlos Keller, Un país al garete. Contribución a la seismología social de Chile (Santiago: Nascimento, 1932). 
even supporting the presidential candidacy of Carlos Ibáñez but at the same time engaged in repeated episodes of political violence- brought about the attempt to trigger a military coup against the civilian government through armed action on September 5, 1938, shortly before the national elections ${ }^{23}$. The results were catastrophic for the MNS. The army did not rebel, many of the naci activists that participated in the armed uprising were concentrated in the Social Security Building (Caja del Seguro Obrero), from which they had fired on the presidential palace of La Moneda, and summarily executed by the police. The MNS leader, Jorge González von Marees, went underground and instructed his followers to vote for the candidate of the anti-fascist Popular Front, a turn of events which probably brought to power the Radical Party candidate, Pedro Aguirre Cerda, leader of the anti-fascist Frente popular, who had opposed both the nationalist Ibáñez and the liberal Gustavo Ross Santa María. ${ }^{24}$ Although the MNS was strongly nationalist, anti-Marxist as well as anti-liberal, and referred to itself (in the classic way that European fascism did) as a "third way" between Capitalism and Communism; after the failure of the attempt to overthrow President Arturo Alessandri Palma, González von Marées, shocked by the massacre of his followers at the hands of the forces of Chile's liberal democracy and relying on the social side of Chile's Nacismo, nearer to Aguirre Cerda's leftist program than to the liberal ideology of Ross Santa María, decided to call his followers to support the former. Since previous elections had shown that the MNS commanded between 3\% (parliamentarian elections of 1937) and 4.5\% (municipal elections of 1938) of the vote and Aguirre Cerda won with a difference of less than $1 \%$ of the vote, it is possible to assume that the naci vote was decisive for the accession to power of the candidate of the Popular front ${ }^{25}$.

Political nationalism in Chile was weakened by the events of SeptemberOctober 1938. The failure of the MNS brought part of its leaders to create a new party of more leftist leaning: the Vanguardia Popular Socialista that functioned for about three years. During the war years, a Nationalist Movement was active in Chile, replicating the political style and the central ideological points of the MNS. In 1945, the Partido Agrario Laborista -PAL- became a meeting point for all the former nationalist and republican groups. This party, led by Jaime Larraín García, became one of the strongest political forces in Chile at the beginning of the 1950s. The PAL presented the candidacy of Ibáñez for the presidential elections of $1952^{26}$.

\footnotetext{
${ }^{23}$ Mario Sznajder, 'A case of Non-European Fascism: Chilean National Socialism in the 1930s,' Journal of Contemporary History 28 (2) 1993, 269-296.

${ }^{24}$ Ibid. 273-283.

25 See also, Jaime Antonio Etcheparre, Hamish I. Stewart, 'Nazism in Chile: A Particular Type of Fascism in South America,' Journal of Contemporary History 30 (4) 1995, 577-605.

${ }^{26}$ Etchepare et al. 'La ideología nacionalista...' 23-25.
} 
Meanwhile, inspired in the example of the Spanish Falange and the JONS and the lessons of the Civil War in that country, a group led by Ramón Callis, Delfín Alcalde, Daniel Frías, Gastón Acuña and father Osvaldo Lira, founded in 1947 the MRNS -Movimiento Revolucionario Nacional Sindicalista (National Syndicalist Revolutionary Movement)- still active under the leadership of Misael Galleguillos. This political association adopted a strongly antiMarxist position all along its existence, struggled against Salvador Allende's government and was coopted by the military government of Chile since 1973.

At the end of 1946, a journalist and ex-leader of the Conservative Party Youth, Jorge Prat Echaurren, founded the bi-weekly -later weekly publicationEstanquero, which ran until mid-1954. Estanqueros was the denomination of the followers of Diego Portales. Prat's kind of nationalism was characterized by strong anti-communism, patriotism, an anti-politicians vision, criticisms to liberal democracy, a stress on the special value of the Spanish tradition and its Chilean Republican and dynamic offshoot, an organic view of society, an antimaterialist approach, and the need of a strong and inspired leader - Prat would support Ibáñez in his successful quest for the presidency in 1952 - and stress the special role of the armed forces in national life ${ }^{27}$.

After the failures of the Ibáñez presidency -1952-1958- and the perception of a rising Marxist menace, Chilean Nationalism entered again the electoral political arena at the end of 1963 when Sergio Onofre Jarpa -an ex-PAL leader- established a new political party, Acción Nacional, that presented Jorge Prat as presidential candidate for the 1964 elections, supported also by the MRNS. Although finally Prat's candidacy was withdrawn, the relative growth of the number of supporters of the Marxist left, combined with what was perceived as a leftist ideological tilt of the victorious Christians Democrats led by Frei - president of Chile 1964-1970 - and the electoral decline of the traditional right wing parties, were behind the formation of a new coalition that would become the Partido Nacional. This novel political party was established in June 1966 as a result of the union of the Conservative Party, the Liberal Party and Acción Nacional.

Some of the demands of the nationalists' followers of Prat in the new party were problematic for the other supporters. The nationalization of mining resources; a strong foreign affairs policy oriented towards the Pacific basin; the demands to reform the political system favouring a stronger executive and a 'depuration' of all democratic institutions and a 'productionist' version of Agrarian Reform were difficult issues for the ex-Liberals and ex-Conservatives to accept. Internal frictions brought about the resignation of Jorge Prat in 1967.

In 1969, Jorge Alessandri Rodríguez -ex-president of Chile 1958-1964became the presidential candidate of the Partido Nacional and of the Chilean right. Various nationalist groups and individuals supported his candidature.

${ }^{27}$ Sergio Miranda C., 'Jorge Prat: Personalidad y Obra,' Portada 36 (1973) 9-11. 
The attempt to present an independent nationalist candidate -General (ret.) Roberto Viaux Marambio-, who had led the October 1969 uprising of the Tacna regiment, failed ${ }^{28}$.

\section{Political Crisis and Nationalism}

After the election of Salvador Allende, leading a coalition of parties headed by Marxist socialists and communists (Unidad Popular - Popular Unity), as president of Chile -4 September 1970- one of the nationalist supporters of Alessandri, Pablo Rodríguez Grez, founded the Movimiento Cívico Patria y Libertad (Civic Movement Fatherland and Freedom) whose main goal was to prevent Allende from becoming president of the country ${ }^{29}$. The failure of the attempted abduction of General René Schneider, the commander in chief of the army, in October 1970, by a commando of civilian nationalists, and their later assassination of the general, did not trigger the military forces' coup ${ }^{30}$.

In spite of the political agreement between the Christian Democrats and Allende's supporting coalition that made possible Allende's accession to the presidency after Congressional approval, Chile's politics turned more violent and polarized than in the preceding four decades.

In March 1971, the Frente Nacionalista Patria y Libertad (Nationalist Front Fatherland and Freedom - FNPL) replaced its civic predecessor. After losing the political battle to preclude Congress from confirming Allende's election to the presidency, its leaders decided to take the path of direct and extra-parliamentary action against the leftist constitutional government of Chile. Many of its members were trained as part of a para-military organization.

28 The details of the Tacnazo, 21 October 1969 are in Florencia Varas, Conversaciones con Viaux (Valparaiso: Nueva Era, 1974) 88-113. Viaux was also involved in the plot to kidnap General René Schneider, in October 1970.

29 The idea behind the foundation of the Movimiento Cívico Patria y Libertad took shape after Allende won the 4 September 1970 election with a small difference of nearly 40.000 votes, something which left him without an absolute majority and in need of Congressional approval -on 24 October 1970 - to become president. Allende could have been blocked by the right together with the Christian Democrats - since they together had a clear parliamentarian majority. Then Congress could constitutionally elect President Jorge Alessandri who had obtained the second majority of votes. After his nomination, Alessandri would have resigned and the Senate President would have become Interim President, calling for a new election. To this election, Eduardo Frei, the outgoing president, could have postulated as a candidate, and probably won, having resolved the problem of the prohibition of consecutive presidential re-election. Many of the supporters of Alessandri favored this solution and adhered to Pablo Rodríguez initiative. Among them we could find a large group of gremialistas, led by Jaime Guzmán Errázuriz. However, their plans were thwarted by Alessandri himself who, on 19 October 1970 called the members of Congress to vote for Allende, in order to confirm the results of the popular vote. The failure of the political alternative is one of the explanations of the kidnapping and assassination of General Schneider.

${ }^{30}$ Varas, Conversaciones con Viaux, 126-139. Patria y Libertad was unrelated to the abduction and assassination of General René Schneider. 
Retired armed forces personnel joined the FNPL and many active officers were secretly linked to it. The leaders of this movement claimed that the CIA did not financially support them as it did regarding other groups opposed to Allende's rule. This, according to Pablo Rodríguez, was due to the fact that the FNPL was a movement linked to a 'nationalist left' and therefore anti-imperialist and antiAmerican. ${ }^{31}$ In spite of this fact, supporters of Allende's government perceived Patria y Libertad as the incarnation of the fascist right.

Increasing polarization brought forth what Pablo Rodríguez called 'hysterically anti-Marxist' elements which joined Patria y Libertad. Powerful business leaders and many right wingers were also in touch with the FNPL, seeing in it a vehicle to overthrow Allende. Rodríguez claimed that during Allende's period, he met with important Chilean entrepreneurs such as Manuel Cruzat, Javier Vial, Jorge Yarur, and others, to whom he presented nationalist ideas of 'integrated enterprises' and capital transfer to the workers. He recalls that none of them objected this scheme, as long as Allende was thrown out of power. Facing the dilemma between ideological 'purity' - meaning limiting Patria y Libertad only to ideologically convinced nationalists - and political 'practicality', Rodríguez preferred the second option, accepting non-ideological elements as well as large capitals support in order to be able to do the dirty work of destabilising the Popular Unity government and triggering military intervention. Rodríguez himself set aims to be achieved in two stages, the first of which culminated on 11 September 1973, when the armed forces deposed Allende, but, at the same time, liquidated Patria y Libertad as a political movement. The second aim, the installation of a nationalist state, was to be carried out by the military with the support and ideological guidance of Chilean modern nationalism - and its anti-political party's attitude- that envisioned wide popular mobilisation and a direct relationship between the authoritarian leadership and the masses ${ }^{32}$.

Polarisation affected other sectors of the Chilean right and especially the National Party encompassing most of the non-fascist and traditional right who opposed Allende. They were led by people formed in the ranks of Chilean nationalism as Sergio Onofre Jarpa -later Pinochet's ambassador to Buenos Aires, Minister of Interior Affairs in the early 1980s and leader of Renovación Nacional, the main post-Pinochet right wing party- and Mario Arnello Romo, one of the founders of the National Party and professionally an expert on National Syndicalism - the subject of his doctoral thesis at the University of Madrid in 1953.

\footnotetext{
31 'Pablo Rodríguez, 'el jefe',' Hoy, 4 April 1979, 22. His version is supported by the declassified CIA's documents that deal with Allende's accession to power.

32 Ibid. 21-22.
} 
On 29 June 1973, an attempt of military putsch was carried out by an armoured regiment in Santiago and members of the FNPL. After some skirmishes in the centre of Santiago the rebellion was suppressed by the chief of staff, General Carlos Prats and the high command of the armed forces remaining loyal to the constitutional government. This failure brought about the flight into exile in Ecuador of Pablo Rodríguez and the most prominent leaders of the FNPL, being momentarily replaced as main leader by Sergio Miranda Carrington of the Tacna group.

Meanwhile, other nationalist groups organized in para-military structures and opposed Allende's government, some of them, especially the Comando Rolando Matus, had carried out destabilizing terrorist activities that created further polarization and produced a highly climate of insecurity ${ }^{33}$.

The incorporation of the nationalists to the military government was done on an individual basis and not necessarily according to their political importance, but to their personal skills. Pablo Rodríguez, the ideologist of Patria y Libertad was mentioned as a possible minister of justice but never called to fulfil this role or any other. Still, Rodríguez became close to colonel Manuel Contreras -commander of the DINA - and also Pinochet's daughter, Lucía Pinochet Hiriart $^{34}$. Federico Willoughby -an ex-conservative and supporter of Jorge Alessandri in 1970- was part of Pinochet's staff in the area of communications. Other nationalists became part of the general's Political Committee: Gisela Silva was in charge of Civil Organizations; Enrique Campos Menéndez -an ex liberal member of Congress- of Cultural Affairs; Gastón Acuña, was placed in charge of Information and Alvaro Puga -a leader of the FNPL so close to the military that he was the only civilian at the Ministry of Defence in the night between the 10 and 11 September 1973- of Public Affairs and a direct adviser to General Pinochet himself ${ }^{35}$.

The influence of the nationalists over military rule was not central but their anti-political vision was very well tuned for military hears. According to their ideological principles, the nationalists could live very well under the definition that Pinochet gave to military rule in Chile in the first months after the coup. They had three possible models: 1 . a period of military transitional rule between two 'political' governments; 2. a civic-military depuration movement

33 See 'Radiografía del delirio político. La ultraderecha,' Punto Final (May 1991) 13.

34 Lucía Pinochet Hiriart, a kindergarten teacher and daughter of the General Pinochet, was chairperson of the Corporación de Estudios Nacionales - CEN (Corporation of National Studies) which published Pablo Rodríguez' book, El mito de la democracia en Chile. 1833-1973 (Santiago: Eves, 1985). In this book, the leader of Patria y Libertad evokes the writings of the early $20^{\text {th }}$ century nationalist historians and thinkers, such as Francisco Encina and Alberto Edwards, as guiding political lights. The CEN was one of the nationalist groups, although, its proximity to Pinochet made it less critical to government policies, even at times of crisis such as the 1982-3 recession, wave of protests and repression

${ }^{35}$ It is interesting to note that Alvaro Puga was one of the leaders of Savador Allende's political campaign to win the presidency of Chile in 1964. He had become an extreme nationalist by 1970 .

Araucaria. Revista Iberoamericana de Filosofia, Política y Humanidades, año 17, no 34. Segundo semestre de 2015. Pp. 177-201. ISSN 1575-6823 e-ISSN 2340-2199 doi: 10.12795/araucaria.2015.i34.09 
or; 3. the establishment of a permanent military regime, Pinochet declared that the military had adopted the second option. This created a situation in which the nationalists felt that their ideological influence could still bear institutional fruits in the future. Moreover, Pinochet's rejection of proposals of rapid political normalization by party leaders indicated that already in the first semester of military rule, the idea of laying the foundations of a new kind of regime was becoming a reality ${ }^{36}$.

The leadership of Patria y Libertad, aware of the recruiting potential imbued in their strong anti-leftist stand, went one step forward by elaborating and publishing their nationalist ideological principles, as a political program closely related to contemporary events and containing what they perceived as solutions to Chile's historical plights. The first Manifiesto Nacionalista was published in November 1971, and until June 1973 six editions were updated and published. The opening statement described nationalism as the most serious barrier to communism in Chile, claiming that Allende's period was not another historical stage but a definitive one in which polarization was total and no middle ranges of political indecision could exist. According to the manifesto, communist demagogy and propaganda advance towards their goal of destruction of the essential values of Western and Christian civilization, central to Chile's ethos, undermining the social structures and thriving on exacerbation of hatred and suicidal confrontation ${ }^{37}$. Nationalist analysis did not blame only the left and direct supporters of the Popular Unity government for the antidemocratic trends that were about to take control and convert the country into a totalitarian Marxist state but had other explanations too. In a long and detailed analysis, Pablo Rodríguez explained the failure of the non-Marxists parties in stopping the progress made by the left, especially after the government of Carlos Ibáñez in the 1950. At the end of Ibáñez' the 'ley maldita' - dammed law: Ley de Defensa Permanente de la Democracia (Permanent Defence of Democracy Law) enacted in 1948 during the administration of Gabriel González Videla that barred Communist participation in Chile's political life and brought to the detention in concentration camps of a large number of Communist leaders and activists and to the exile of others, was derogated. This fact, for Rodríguez, added to the weakness, divisiveness and corruption of the non-Marxist political parties that allowed Salvador Allende at the head of the FRAP -Frente Revolucionario de Acción Popular (Revolutionary Front for Popular Action) - to obtain the second plurality, losing the presidential election in which Jorge

\footnotetext{
${ }^{36}$ For a discussion of this point and the chronological sequence of events see, Ascanio Cavallo, Manuel Salazar and Oscar Sepúlveda, La historia oculta del régimen militar (Santiago: Ediciones La Epoca, 1988) 20-21.

${ }^{37}$ Pablo Rodríguez G., Manifiesto Nacionalista (Santiago: Frente Nacionalista Patria y Libertad, 1973) $6^{\text {th }}$ edition, 4-5.
} 
Alessandri was elected, in 1958 , by thirty thousand votes ${ }^{38}$. The nationalist conclusion was that Chile suffered from an institutional vacuum both at the state organization level as well as at the level of political organizations.

The events after 4 September [1970] were a result of a long process in which the Political Parties were in crisis, since they were unable to prevent the accession to power of an antidemocratic, internationalist and minority movement, against the clamour (outcry) of the national majorities that did not accept being surrendered to the voracity of $[\mathrm{M}] \operatorname{arxism}^{39}$.

This evolved in the 1980s, according to the needs posed by the 'foundational' drive of military rule to the idea that

...in Chile there was never a democratic regime, according to the real meaning of the word ${ }^{40}$.

Still, Chile's society possessed also very positive elements with which it could, according to the nationalists, fight and defeat communism. Patria y Libertad and its supporters were a manifestation of this kind. Another one, at the institutional level and far more powerful as well as not less compromised with the destiny of the country, were the armed forces. Historically, nationalist groups in Chile enjoyed good and close relations with the armed forces. According to their historical views, the armed forces were patriotic and nationalist by definition, regardless of their political character or programs of nationalism. The armed forces, in nationalist eyes, were the only safeguard left for Chile's non-Marxist historical institutional arrangements. In 1973 -before the coup- the military were deeply worried due to three facts: 1. the Marxist orientation of the government, guided by the Communist Party; 2. the possible disappearance of the traditional armed institutions and their replacement by militias or popular armies, following the experience of countries controlled by international communism and; 3 . the humiliations suffered by a General Viaux Marambio whose influence over young officers and the troops augmented significantly, when he was tried for political crimes ${ }^{41}$.

${ }^{38}$ Idem, Entre la democracia y la tiranía (Santiago: s.n., 1972) 12. It is interesting to point out that the author mentions the fact that Jorge Alessandri won the 1958 election by a plurality of 30.000 votes, a similar plurality with which Allende won the 1970 election from Alessandri. (p. 27). Another interesting detail brought up by Rodríguez is the fact that Antonio Zamorano Herrera - El Cura de Catapilco - obtained 40.000 votes that, if obtained by Allende, would have given him a clear majority 10.000 votes (p. 12).

39 Ibid., 42.

40 Pablo Rodríguez G., 'Prefacio' El mito de la democracia en Chile (Santiago: Eves Ediciones, 1985). In this book, Rodríguez sustains his hypothesis by profusely quoting $20^{\text {th }}$ century Chilean historians, beginning with Alberto Edwards. See also, Arturo Fontaine Talavera review of Pablo Rodríguez book in Arturo Fontaine Talavera, Pablo Rodríguez Grez, 'El mito de la democracia en Chile (1985)', Revista Ciencia Política 7 (2) 1985, 221-223.

41 Idem, Manifiesto nacionalista, 6. 
Nationalism lacked a strong and cohesive political leadership, or a single decisive leader. Jorge Prat, the traditionally and widely accepted leader of nationalism had died in November 1971. His last interview to a nationalist publication, Tacna, in May, six months before his death, clearly stated his vision and verdict about the destiny of Chile under Allende's rule:

...I am sure that the country, and specially the weak people, is entering a stage of suffering as never known before. The adopted economic measures; the enormous responsibility placed on the shoulders of an unable and badly politically selected, the bureaucracy that has to manage the enterprises being placed under state control; the lack of security and mistrust which will prevent creative action by the ablest of men; and above all, the sterile, negative and criminal divisiveness imbued in the class ridden propaganda that the country receives day by day; all this will bring unemployment, economic paralysis, lack of supplies, budgetary deficit and inflation. We will live in a period worse than the one following a lost war ${ }^{42}$.

The death of the leader was another factor leading to the enunciation of a clear political platform that would serve as a basis of action and criteria of direction, once the nationalists would achieve their immediate goal: victory over Marxism in Chile.

Together with saving the country in this dangerous moment, we aspire to establish the first Chilean Nationalist State inspired in duty, discipline, and social justice. Worthless will be freedom from Marxist oppression if we have no other destiny than misery, inequality and continuous social strife ${ }^{43}$.

A political platform, as clear and attractive as it may be, could not, by itself, replace the lack of political leadership. Nationalists saw Chileans as people that loved freedom and democracy and are used to live under a state of law '... which excludes the arbitrariness and the absolutism of the tyrant, be it called dictator or the party's central committee ${ }^{\prime 44}$. Here, Chilean nationalism is pointing to three elements -democracy, libertarianism and a state of law- that, at least theoretically, could place their desired nationalist state within the realm of Western democracies. But when defining the place of nationalism in the popular right-left political continuum the nationalists will take the Third Way position, historically associated with the ideological origins of fascism. While on principle rejecting the vulgarity of terms as left and right to define their political position, they will claim:

42 'Prat, Visionario,' Tacna (3, Mayo 1971), quoted from Miranda, 'Jorge Prat: Personalidad y Obra,'...8-9. Sergio Miranda Carrington, a nationalist lawyer and supporter of the idea of a indefinite term military government led the Grupo Tacna during Allende's government and was linked to General Viaux Marambio.

43 Rodríguez, Manifiesto nacionalista, 7.

44 Ibid. 9. 
We are from the right, as we love [our] history and feel dignified by it.; we are of the left, as we identify with deprived and the exploited; we are of the right, as we aspire to restore order and the empire of law; we are of the left, as we aspire to give ourselves an advanced organization, able to conquer the future. ${ }^{45}$

Therefore, and in order to understand and conciliate apparent contradictions in the way Chilean nationalists presented their views in the 1970s and 1980s, the terms, democracy, libertarianism and state of law must be placed in the perspective and conceptual framework of this movement. The nationalist program of 1973 contains six points directly related to the above mentioned concepts. It claims that Chile's nationalist doctrine can be synthetized into six fundamental points to be achieved in the political practice: 1. A Fundamentalist State; 2. an Authoritarian Government; 3. people possessing Collective Responsibility and Social Discipline; 4. a Youth program; 5. an Integrated Enterprise System and; 6. a Functional Democracy. In this case the above mentioned concepts of democracy, libertarianism and state of law are also closely related to what Chilean nationalists considered an atypical historical development, as compared with the Latin American framework, and the six resulting doctrinal programs from Chile's different historical experience are unrelated, again according to the nationalist view, with the historic development of fascism and Nazism in Europe. The searching for local roots leads directly to the political work of Diego Portales, seen by many as the founder of Chile, as stable state through the enactment of the 1833 Constitution. Patria y Libertad's leader, Pablo Rodríguez, quoted Portales in 1822, claiming that then, as now, his words resounded with a special clearness:

The democracy so preconized by dreamers is absurd in countries as the [A]mericans, full of vices and where citizens lack all virtue, as necessary to establish a real republic....The republic is the system to be adopted; but, do you know how do I understand it in these countries? A strong, centralized government whose men are a real model of virtue and patriotism, and in this way, straightening the citizens on the road of order and of virtues [is needed]. When they become moralized, let come a completely liberal government, free and full of ideals, where all citizens will take part. This is what I think and any man with an average judgement will think the same ${ }^{46}$.

Portales model of state was preconized by the nationalists and other groups of the Chilean right as the one that imbued the real civic virtues that transformed Chile in the $19^{\text {th }}$ century in an island of stability in the midst of the anarchic

${ }^{45}$ Ibid., 8. On the subject of the Third Way and Fascism see Zeev Sternhell, Mario Sznajder, Maia Asheri, Naissance de l'ideologie fasciste (Paris: Fayard, 1989) 11-51.

${ }^{46}$ From a letter sent by Diego Portales to José Manuel Cea on 10 February 1822 as quoted in Rodríguez, El mito de la democracia en Chile, 25. 
sea of Latin America, a serious contradiction appeared around the social and individual education to the qualities Portales himself considered necessary for the establishment of the real republic: order and virtues, or a high level of civil morality. If the argument was that Portales state was imbued with these qualities and was a progressive one, working towards the foundation of the 'real republic', then, even superficial historical analysis would clearly show that it had failed in its purpose. The liberal period that followed the three conservative decades, from 1830s to 1860 s showed the existence of profound cleavages that rapidly surfaced. Moreover, the establishment of the Parliamentarian Republic, as the result of the civil war of 1891, brought the opposite of Portales ideals to power: corruption and fractional interests. Then, as the nationalists themselves claimed, Chile lived since 1925 under a mythical democracy degenerating into a "particracy" in which political sectors and group interest groups were always preferred to those of the nation. Pablo Rodríguez explains military intervention in 1973 as a result of the existence of a failed democracy:

\begin{abstract}
With the fall of Allende, people understood that it was not just another government that fell. It was the political system which, undermined by demagogy, class hatred, terrorism, violence and politiquería ['petty politics', used in a contemptuous way], was ending. Marxism was not, between Chileans, a political coincidence nor a lucky achievement of political adventurers. It was the systematic taking advantage of the vacuum and weaknesses of a formal democracy. The fractures of the system were many and through them, the vices that feed totalitarian communism could sneak in ${ }^{47}$.
\end{abstract}

This nationalist line of analysis could only mean not only that Portales ideals were not fulfilled because the model he proposed had changed, but also that the new form of authoritarianism, in historical terms, was a long range issue, since the civic virtues needed to transform the republic in 'real political property of the citizens body' could only be achieved over long historical periods of authoritarian rule in which it would mature. Therefore, the failure of the model itself was evident and antithetical to the nationalist dream of integration and unity, which they wanted to achieve under strong authoritarianism. The failure was in the lack of capacity to sustain itself in power until civic virtues become the norm for most of the citizenschip, or perhaps, its inherent elitist nature. It favoured clear conservative political conclusions.

Portales himself, more than 'a man for all seasons' working in the extraordinarily difficult conditions of the disintegration of the Spanish American Empire -in which the society and culture of Chile had developed and the flux of liberal democratic and republican ideas, in the name of which the separation

${ }^{47}$ Ibid., 156.

Araucaria. Revista Iberoamericana de Filosofía, Política y Humanidades, año 17, n 34. Segundo semestre de 2015. Pp. 177-201. ISSN 1575-6823 e-ISSN 2340-2199 doi: 10.12795/araucaria.2015.i34.09 
from Spain had been fought- can only be seen as a sceptic ${ }^{48}$. Observation of political reality -war and chaos- brought about the adoption of the republican ideal of an impersonal, strong and executive state, but at the same time, not believing that the social bases for such a state -the needed virtues of citizenship and social organization- could exist, therefore, relying on authoritarianism, a concept not necessarily linked to what were claimed to be Portales ideals. On the contrary, Portales himself, doubtful about his own society's republican and democratic capacities, admitted that the citizens' virtues have to be inculcated, but he seemed to leave open the space for democratization for the time when they will be moralized.

Undoubtedly, certain readings of Portales role and deeds, mostly of mythical character and suffering from the kind of extrapolations and applications that do not serve neither serious historical nor political readings, could be very useful to the nationalists - and other groups which supported military intervention and rule in Chile- for the creation of a historical myth -or various versions of the same myths with different political nuances, leading to different contemporary political conclusions in order to serve as tools for obtaining legitimacy in the process of demise of Chilean democracy in favour of an authoritarian experiment. This legitimacy, translated popularly in terms such as Chilenidad, traditionalism, common values or even the basic foundations of the nation and the state, were presented with the mechanism that interrelated history and politics. In these processes, historical facts and interpretations - also at the level of historical myths - became an integral part of the contemporary political discourse, mainly, for legitimization purposes of actual policies or trends, in an attempt to demonstrate that similar attitudes produced good results in the past. In parallel, the contemporary political discourse becomes inundated with historical figures and examples, setting the past in terms of current politics ${ }^{49}$.

Chilean nationalism could not escape the explanatory dilemma about the main role of the state, and by defining it as an integrating state it was ascribing to it a role well above the simple functional political-administrative meaning of the word. Nationalism was fighting to create the kind of state -Estado Integradorthat would transcend social classes, ideologies, interests and become a factor of unification and national cohesion. In order to achieve this goal, institutions should favour solidarity and equality between Chileans; and help to harmonize interests placing those of the nation above private or sectorial divisions. In short, this kind of state should create '...a moral and economic community, strongly rooted in

${ }^{48}$ On Diego Portales and the historiographical discussion about the interpretation of his role and ideas see the brilliant conclusions of Alfredo Jocelyn-Holt Letelier, El peso de la noche. Nuestra frágil fortaleza histórica (Santiago: Planeta, 1998) 2 2n edition, 119-143.

${ }^{49}$ On this subject see Ana María Alonso, 'Effects of Truth: Re-Presentations of the Past and the Imagining of Community.'

Araucaria. Revista Iberoamericana de Filosofía, Política y Humanidades, año 17, $\mathrm{n}^{\circ} 34$. Segundo semestre de 2015. Pp. 177-201. ISSN 1575-6823 e-ISSN 2340-2199 doi: 10.12795/araucaria.2015.i34.09 
national values, identified with the common interests of our people ${ }^{50}$. Harmony and arbitration between different interests are key words of this model. The nation can exist and transcend only when economic harmony, social peace and public tranquillity are the norm, and it is the existence of these that strengthen the state also. In the Manifiesto nacionalista the relationship between nation and state is unclear. If the harmonizing and pacifying nationalist state is so sorely needed, as it was also needed in the past, the nation probably suffered from high levels of divisiveness between classes, groups, ideological tendencies and so forth. More than one tradition coexists with the others and there is no agreed interpretation of the common past either. Then, one of the main tasks of the integrating state is probably to create the nation itself, since it is difficult to see in a highly divided social body the unifying qualities a nation should theoretically possess. This is another factor why, in its search for legitimacy, the nationalist 'golden age' has to be found in the past and is located in Portales's period, which could be otherwise interpreted not only as the period of nation building, but also as the period of statebuilding in which, more than tradition and organic, unifying national factors, the basic institutions of statehood were firmly established in Chile. A new process of nationalist modernization would take care of this former developments that included liberal as well as socialist trends of institutionalization in the form of both defence of private property and entrepreneurship and, at the same time, an enlargement of the economic role of the state has to be regenerated into an unified philosophy of development that subordinates everything to one central criteria: the interests of the nation.

Their third way proposed a productionist and corporativist economic model closely related to the one developed by national revolutionary syndicalism and different variants of fascism in Europe in the 1920s and 1930s. In its Chilean version it called for the transformation of the capitalist enterprise into an "empresa integrada de trabajadores" (integrated workers enterprise) in which all the productive factors: capital, labour and organization ${ }^{51}$ that would unite in order to enhance productivity and be rewarded 'in an equitable way and according to its importance' from the benefits of wealth creation. Enterprises would, in this model, be managed by representatives of all the productive sectors and the role of the state would be to regulate the functioning of these bodies and to become arbitrator in case of difficulties arising from 'the productive co-management'. The main goal the nationalists hoped to achieve through the application of this model was the elimination of class confrontation between capitalists and workers. Therefore the state, in its regulatory capacity, was called to approve the opening of firms in which co-management was pre-agreed and in which production relations are defined in advance. They also proposed

${ }^{50}$ Rodríguez, Manifiesto nacionalista. 21-22.

${ }^{51}$ By organisation, the nationalists mean the managerial/technocratic sector.

Araucaria. Revista Iberoamericana de Filosofía, Política y Humanidades, año 17, n 34. Segundo semestre de 2015. Pp. 177-201. ISSN 1575-6823 e-ISSN 2340-2199 doi: 10.12795/araucaria.2015.i34.09 
a system of social amortization. This would consist in the regulated and precontracted acquisition by the workers of a percentage of the enterprise capital in order to transform it, in the long term, in a workers' enterprise. The first step from capitalism to an integrated economy was, for Patria y Libertad, to incorporate workers into the directory of already existing capitalist enterprises. Economía social de mercado (Social market economy), a term that would become emblematic of the model established by the military on the basis of a purely neoliberal economic model, had for Chile's nationalists a definite and positive meaning in the kind of model based on the integrated enterprise that would be succeeded by the workers enterprise, in order to bring about a situation in which the majority of workers, seemingly protected by what the nationalists saw as poor and false provisional benefits and plans, suffering from bureaucratically inflated costs and supplying scant benefits, would become real owners of their own fate. State enterprises should not be completely eliminated but will only take care of infrastructural tasks and would also be structured according to the model of the integrated enterprise. On the long range, all enterprises, involved in what the Manifiesto nacionalista calls a sistema de amortización social (System of Social Amortization) would perform a slow but steady transfer of capital to the workers, creating a situation of equitable economic empowerment for large sections of the population.

It is necessary to point out that models of this kind, giving substance to the paradigm of 'neither right nor left' were the product of the revolutionary, syndicalist revision of Marxism that had met radical nationalism in the eve of the First World War. After that war, Alceste De Ambris elaborated detailed programs of this kind to confront both the Marxist and the liberal political models with the aim of producing a system that would at the same time preserve the efficiency and incentives of capitalism and the social justice view of Marxism. De Ambris model of national revolutionary syndicalism was incorporated both to the first fascist program of June 1919 and to the Carta del Carnaro, the Constitution of the Regency of Fiume under Gabriele D'Annunzio, in September 1920. ${ }^{52}$ Later, fascist Italy and fascists everywhere found in De Ambris work a source of inspiration for the development of a corporativist view of the state, the economy and society. This model found echoes in Chile through the dictatorship of General Miguel Primo de Rivera, who was seen by Carlos Ibáñez del Campo as a source of inspiration in the late 1920s. Furthermore, The Movimiento Nacional Socialista de Chile-MNS- in the 1930s, and other Chilean nationalist and quasi-fascist groups found their 'third way' socio-economic formula in the above mentioned model and also in the version of it developed in Spain by

${ }^{52}$ On this subject see, Mario Sznajder, 'The Carta del Carnaro and Modernization,' Tel Aviver Jahrbuch fur deutsche Geschichte 19 (1989), pp. 439-461.

Araucaria. Revista Iberoamericana de Filosofía, Política y Humanidades, año 17, no 34. Segundo semestre de 2015. Pp. 177-201. ISSN 1575-6823 e-ISSN 2340-2199 doi: 10.12795/araucaria.2015.i34.09 
José Antonio Primo de Rivera and Falange Española which included strong Catholic mystique elements ${ }^{53}$.

It was very clear to people like Pablo Rodríguez, Sergio Miranda, Gastón Acuña o Mario Arnello that the historical opportunity to reach large groups of population transforming nationalism from divagations of the intellectual elite into a real political force was due to the activist and central role they were playing in opposing Marxism. However, it was also clear to them that unlike many of their circumstantial political allies, as the Conservative, the Liberals (the right) or many Christian Democrats (the Centre) who, besides defending well entrenched economic and social interests, would be satisfied with a return to the statu quo ante with the Marxist left displaced and barred from power, the nationalists should strive for real and deep changes, in order to transform Chile into the Estado Integrador [Integral State].

Undoubtedly, the kind of Chilean nationalism preconized by Patria y Libertad has very little to do with the then existing democratic traditions and with the conservative views of Chile in the $19^{\text {th }}$ century. The imagery built by Patria y Libertad around Portales has clear historical-mythical proportions. It is not a call to replicate the glories of the past but to build a future in the same spirit and with some of the contents Portales casted into Chilean politics and institutions. Still, Portales imagery as well as a non-detailed overview of his period served to substantiate the idea of the same nation that achieved victory in Yungay and conquered the dessert in the North and Araucanía in the South. This nation could successfully solve its problems, as serious as they may be, and create a bright future. In this kind of Chilean nationalism, although the rejection of liberal political, social and economic values is almost absolute, a relatively clear project of modernization is attributed to the national community rather than to the class or the individual it becomes a structure. It was a mobilizing movement that believes in another model of politics, conducted rather through the main organized actors of civil society -the autonomous intermediate bodies- than through the political parties subject to the 'iron law of oligarchy'.

\footnotetext{
${ }^{53}$ There are many publications on this subject, but as an analysis of the combination between José Antonio Primo de Rivera's ideology and Francisco Franco's policies see Stanley G. Payne, Franco y José Antonio. El extraño caso del fascismo español. Historia de la Falange y del Movimiento Nacional (1923-1977) (Barcelona: Planeta, 1998) especially the second part of the book on José Antonio Primo de Rivera, 149-377. The English version is Fascism in Spain (1923-1977) (Madison, WI: Wisconsin University Press, 2000).
} 


\section{Conclusions}

Nationalisms in Latin America, politically confronting a multifaceted problem of identities, social miscegenation, past and present cultural influences, adverse political models living through serious crises, and the need to find a workable model of development, use -and abuse- history as a source of inspiration but mostly, as a reservoir of legitimacy. The particular details of each case are different but the pattern is similar. All of them defended their ideas in the name of 'the nation' -and not of the individual, nor a particular class or elite and not even in the name of religion. History provided not only myths of past glory and legitimacy, but also a right path into the future because the nation was born in it and would build itself always looking into its bases, rooted in that past, in its history. In history they looked for the laws governing human existence and development. Figures like Portales, Rosas and San Martín, Artigas and Bolívar, Sucre and Santa Cruz were not only founding fathers and heroes, but also moral models and confronters of adversity who achieved their goals. As such, they had set not only precedents but also effective models that should be seriously studied in order to extract the principles that could again lead 'the nation' to the heights achieved under the leadership of the founding fathers.

In Latin America, perhaps more than in other corners of the world due to the complex past, from a nationalist point of view, the leaders of the nationalist movements needed "a history" and historians to stress the role of the nation. Migration in all directions, miscegenation, as well as ethnic and socioeconomic and cultural cleavages placed enormous pressures on each 'nation'. The states seemed sometimes as tools in the hands of local oligarchies and foreign interests, disregarding the nation, disregarding 'the people'. Modern nationalisms in Latin American tended to become fundamentalist and antiimperialist as well as mass mobilizing. The ideology was elaborated in a constant dialogue between nationalist politicians and nationalist historians, in which the influences were mutual. 


\section{Referencias bibliográficas:}

Alonso, Ana María: "The Effects of Truth: Re-Presentations of the Past and the Imagining of Community," Journal of Historical Sociology, 1 (1) 1988. Anderson, Benedict O.: Imagined communities: reflections on the origin and spread of nationalism (London: Verso, 1987).

Benavente, Andrés: "La alternativa nacionalista en el régimen militar", (manuscrito inédito, 1982).

Brading, David: "Patriotism and the Nation in Colonial Spanish America," in Luis Roniger, Mario Sznajder (eds.) Constructing Collective identities and Shaping Public Spheres. Latin American Paths (Brighton: Sussex Academic Press, 1998).

Cleary, David: Race, nationalism and social theory in Brazil: rethinking Gilberto Freyre, University of Oxford, Working Papers Transnational Communities Programme 1999.

Donoso, Ricardo: Francisco A. Encina: Simulador (Santiago: Editorial Ricardo Neupert, 1969) 2 vols.

Vives, Alberto Edwards: La fronda aristocrática en Chile (Santiago: Imprenta Nacional, 1928).

Encina, Francisco A.: Nuestra inferioridad económica: sus causas, sus consecuencias (Santiago: Imprenta Universitaria, 1911).

Etchepare Jaime Antonio, García Víctor, Valdés Mario: "La ideología nacionalista y su proyección partidista en Chile 1925-1973," Politica y Geoestrategia 44 (1987).

Etcheparre, Jaime Antonio, Stewart, Hamish I.: "Nazism in Chile: A Particular Type of Fascism in South America," Journal of Contemporary History 30 (4) 1995.

Fontaine Arturo et al (eds.) Nuestro camino (Santiago, Ediciones Encina, 1976).

Fontaine Talavera, Arturo: "Pablo Rodríguez Grez, "El mito de la democracia en Chile (1985)", Revista Ciencia Política 7 (2) 1985.

Gellner, Ernest: Nations and nationalism (Oxford: Basil Blackwell, 1983).

González von Marees, Jorge: El problema del hambre. Sus causas y solución (Santiago: Ercilla, 1937).

González von Marees, Jorge: El mal de Chile. Sus causas y remedios (Santiago: Talleres Gráficos Portales, 1940).

Griffin, Charles C.: "Francisco Encina and Revisionism in Chilean History," Hispanic American Historical Review, 37 (1) 1957.

Jocelyn-Holt Letelier, Alfredo: El peso de la noche. Nuestra frágil fortaleza histórica (Santiago: Planeta, 1998) 2 $2^{\text {nd }}$ edition, 119-143. 
Jocelyn-Holt Letelier, Alfredo: El Chile perplejo. Avanzar sin transar, transar sin parar (Santiago: Planeta, 1998).

Keller, Carlos: Un país al garete. Contribución a la seismología social de Chile (Santiago: Nascimento, 1932).

Krieger, Joel: (ed.), The Oxford Companion to Politics of the World (New York, Oxford: Oxford University Press, 1993)

Le Bon, Gustave: The crowd: a study of the popular mind (London: T. Fisher Unwin, 1908).

McGee Deutsch, Sandra: Las derechas. The Extreme Right in Argentina, Brazil and Chile, 1890-1939 Stanford, CA: Stanford University Press, 1999).

Miranda C., Sergio: “Jorge Prat: Personalidad y Obra,” Portada 36 (1973).

Oliveira Vianna, Francisco José de: As Populaçoes Meridionais do Brasil; historia, organização, psycologia (Sao Paulo: Companhia Editora Nacional, 1933) 3rd edition.

Palacios, Nicolás: La raza chilena: su nacimiento, nobleza de sus oríjenes (Valparaíso: Imprenta y Litografía Alemana, 1904).

Payne, Stanley G.: Franco y José Antonio. El extraño caso del fascismo español. Historia de la Falange y del Movimiento Nacional (1923-1977) (Barcelona: Planeta, 1998).

"Prat, Visionario," Tacna 3 (Mayo 1971).

Rock, David: Authoritarian Argentina. The Nationalist Movement. Its History and its Impact (Berkeley, CA: California University Press, 1993) 4445.

Rodríguez G., Pablo: Manifiesto Nacionalista (Santiago: Frente Nacionalista Patria y Libertad, 1973) $6^{\text {th }}$ edition.

"Pablo Rodríguez, 'el jefe'," Hoy, 4 April 1979.

Rodríguez, Pablo: El mito de la democracia en Chile. 1833-1973 (Santiago: Eves, 1985)

Rojas, Ricardo: La restauración nacionalista, informe sobre la educación (Buenos Aires: Ministerio de Justicia e Instrucción Pública, 1909).

Skidmore, Thomas E.: Black into White. Race and Nationality in Brazilian Thought (Durham, NC: Duke University Press, 1993).

Salgado, Plinio: O que é o integralismo (Rio de Janeiro: Schmidt, 1935) 3. ed.

Smith, Anthony: The ethnic origins of nations (Oxford: Basil Blackwell, 1987).

Spektorowski, Alberto: The Origins of Argentina's Revolution of the Right (Notre Dame, IND: Notre Dame University Press, 2003).

Sternhell, Zeev, Sznajder, Mario, Asheri, Maia: Naissance de l’ideologie fasciste (Paris: Fayard, 1989). 
Subercaseaux, Guillermo: Los ideales nacionalistas frente al doctrinarismo de nuestros partidos politicos históricos (Santiago: Imprenta Universitaria, 1918).

Sznajder, Mario: "The Carta del Carnaro and Modernization," Tel Aviver Jahrbuch fur deutsche Geschichte 19 (1989).

Sznajder, Mario: "A case of Non-European Fascism: Chilean National Socialism in the 1930s," Journal of Contemporary History 28 (2) 1993.

Alberto Torres, O problema nacional brasileiro; introducção a um programma de organização nacional (Sao Paulo: Companhia editora nacional, 1933).

Trindade, Helgio: "Fascism and Authoritarianism in Brazil under Vargas (1930-1945)," in Stein Ugelvik Larsen (ed.) Fascism Outside Europe (Boulder, CO: and New York: Social Science Monographs and Columbia University Press, 2001).

Varas, Florencia: Conversaciones con Viaux (Valparaiso: Nueva Era, 1974).

"Radiografía del delirio político. La ultraderecha," Punto Final (Mayo 1991). 
